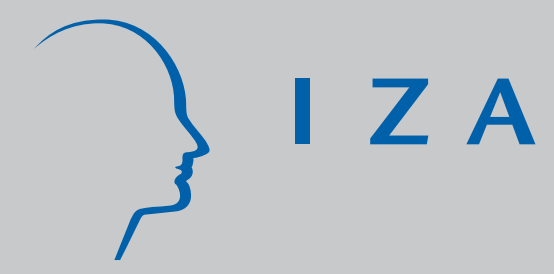

IZA DP No. 683

Is Education Used as a Signaling

Device for Productivity in

Developing Countries? Evidence

from Ghana

Eric Strobl

January 2003 


\title{
Is Education Used as a Signaling Device for Productivity in Developing Countries? Evidence from Ghana
}

\author{
Eric Strobl \\ CORE, Catholic University of Louvain, \\ IZA Bonn \\ Discussion Paper No. 683 \\ January 2003
}

\author{
IZA \\ P.O. Box 7240 \\ D-53072 Bonn \\ Germany \\ Tel.: +49-228-3894-0 \\ Fax: +49-228-3894-210 \\ Email: iza@iza.org
}

This Discussion Paper is issued within the framework of IZA's research area Labor Markets in Transition Countries. Any opinions expressed here are those of the author(s) and not those of the institute. Research disseminated by IZA may include views on policy, but the institute itself takes no institutional policy positions.

The Institute for the Study of Labor (IZA) in Bonn is a local and virtual international research center and a place of communication between science, politics and business. IZA is an independent, nonprofit limited liability company (Gesellschaft mit beschränkter Haftung) supported by the Deutsche Post AG. The center is associated with the University of Bonn and offers a stimulating research environment through its research networks, research support, and visitors and doctoral programs. IZA engages in (i) original and internationally competitive research in all fields of labor economics, (ii) development of policy concepts, and (iii) dissemination of research results and concepts to the interested public. The current research program deals with (1) mobility and flexibility of labor, (2) internationalization of labor markets, (3) welfare state and labor market, (4) labor markets in transition countries, (5) the future of labor, (6) evaluation of labor market policies and projects and (7) general labor economics.

IZA Discussion Papers often represent preliminary work and are circulated to encourage discussion. Citation of such a paper should account for its provisional character. A revised version may be available on the IZA website (www.iza.org) or directly from the author. 
IZA Discussion Paper No. 683 January 2003

\section{ABSTRACT \\ Is Education Used as a Signaling Device for Productivity in Developing Countries? Evidence from Ghana*}

This paper investigates whether education is used as a signaling device for worker productivity in developing countries. To do such we employ a simple test of employer learning on Ghana manufacturing data. We find no evidence of educational signaling for individuals who were hired through direct contacts in the firm, and thus for workers for which employers arguably have more information about their true abilities. In contrast, education acts as signal for workers who were hired through more formal channels, although only for those that do not receive on-the-job-training.

JEL Classification: $\quad$ 012, J30

Keywords: educational sorting, on-the-job-training, Ghana

Eric Strobl

CORE

Université Catholique Louvain

Voie du Roman Pays 34

1348 Louvain-la-Neuve

Belgium

Tel.: +32 10474328

Fax: +32 10474301

Email: strobl@core.ucl.ac.be

\footnotetext{
* Thanks are due to Francis Teal from the CSAE at the University of Oxford for provision and help with the data and to Mark Cassidy, Holger Görg, Frank Walsh, and participants of the 2002 DESG conference in Nottingham for comments on an earlier draft. All remaining errors are the author's.
} 


\section{Section I: Introduction}

The matching of employees to employers will almost certainly involve some informational uncertainty given that search and information acquisition costs are nonnegligible. It has been argued that one way in which employers may respond to the high costs of acquiring information on the productivity of potential employees is to use other more easily observable characteristics, in particular the educational level, to infer ability. ${ }^{1}$ As a matter a fact, a number of studies for developed countries seem to indeed suggest that educational signaling is an important feature of labour markets; see, for example, Weiss (1985) for a review of earlier studies and Altonji and Pierret (2001), Bauer and HaiskenD eNew (2001), Bedard (2001), and Frazis (2002) as examples of the more recent literature. Arguably there may be an even greater role for educational signaling in developing countries, where channels for the exchange of labour market information, such as employment exchange offices and vacancy advertising, are often underdeveloped, if not non-existent, and thus information acquisition costs are likely to be larger. ${ }^{2}$

Of course, labour markets may respond to informational uncertainties about the productive ability of workers in other ways than through educational signaling. One possibility is to match workers to firms through informal channels, such as hiring the employer's relatives and acquaintances and/ or relatives and acquaintances of their existing employees. Although this may limit their pool of potential workers, it is also more likely to provide employers with superior information on their ability. ${ }^{3}$ Indeed features commonly attributed to developing countries, such as the remoteness of rural labour markets, restricted

\footnotetext{
1 Students will at the same time take this into consideration when choosing their optimal level of schooling. 2 The International Labour O rganisation, for instance, argues that these features of the labour market make job search less meaningful, and hence argues for a different definition of unemployment for developing countries; see Byrne and Strobl (2001).

3 The idea that education may have less of a role as a signaling device when workers are hired through informal channels was first argued and investigated by Albrecht (1981).
} 
access to education, the importance of the extended family, and the tight-knit networks of communities, make this an attractive alternative to educational signaling. In the most extreme cases, such as where access to education is completely restricted or the remoteness of the labour market or cultural aspects restricts the pool of potential workers to only individuals already well known to the employer, educational signaling may not feature as an option at all.

Although there is now a large literature on aspects such as the determinants and returns to schooling and the role of education in learning on the job for a number of developing countries ${ }^{4}$, to the best of our knowledge there is currently no single study addressing the issue of educational signaling in a developing country context. In this paper we thus investigate the importance of education as a signaling device using employeremployee matched data for G hana manufacturing. Specifically, we employ a simple test developed by Altonji and Pierret (2001) that explores the role of education in how employers learn about the productivity of their employees over time. ${ }^{5}$ The intuition behind this test is straightforward but attractive: as employees spend more time in the labour market and their true productivity is revealed, the use of education as a signaling device should become less important. Given the potential importance of informal channels in the hiring process in developing countries in reducing informational uncertainty, as just argued, we are careful in our analysis to distinguish between those that were hired through informal networks and those that were hired through more formal channels.

The remainder of the paper is organized as follows. In the following section we briefly review the empirical approaches to testing educational signaling and outline the test

\footnotetext{
${ }^{4}$ See Behrman's (1999) chapter on "Labor Markets in Developing Countries" in the Handbook of Labor Economics.

${ }^{5}$ Foster and Rosenzweig (1994) find some evidence that employers in Asia learn about their employees' productivity over time.
} 
employed in this paper. Section III describes our data set and provides summary statistics. Empirical results are given in Section IV. Finally, concluding remarks are in the last section.

\section{Section II: Testing for Educational Signaling}

It can be considered a long-standing stylized fact from the empirical literature on wage determination that workers with higher levels of education tend to have higher wages, and studies using data for developing countries have been no exception to this. ${ }^{6}$ Traditionally the most common explanation for this finding was that time spent in school increases wages by directly increasing the worker's productivity through human capital acquisition, thus making appeal to standard human capital theory. Since the early 1970's, however, a compelling competitor to the pure human capital explanation has emerged. ${ }^{7}$ Specifically, it has been argued that better educated workers are not a random sample of the total population of workers since those better educated workers are likely to also have other characteristics that positively affect their productivity, such as lower propensities to quit, better health, higher motivation, to name but a few. If some of these latter features are not directly observable to the employer when the employee is first hired and/ or in the early part of their work history, then employers may use education as a signaling device for productivity. Similarly, potential employees will take such educational signaling into consideration when making their optimal schooling decision.

Empirically assessing the role of educational signaling is, however, notoriously difficult and has generally relied on indirect evidence for support. Specifically, many of these

\footnotetext{
6 Earlier studies for developing countries found that the returns to education were considerably larger than those for developed countries. However, it has been pointed out that these earlier estimates are likely to suffer from considerable biases and are likely to be overstated; see Behrman (1999).

7 O ne should note that the signaling explanation does not advocate that the human capital explanation has no role to play, but rather that is not the sole explanation.
} 
studies have appealed to the implications of diploma effects, regional and temporal differences in educational access and school attendance laws, and differences in occupation types and hiring behaviour, amongst other things, for educational signaling as support. Although some would argue that the evidence is not always that convincing, it is fair to say that most of these studies do find some role for educational signaling in the labour market. A literature with more recent roots, first pioneered by Farber and Gibbons (1996) and then extended by Altonji and Pierret (1999) ${ }^{8}$, has, in contrast, focused on examining the process of employers learning about employees' productivities over time and the relationship of this to the returns to education. Accordingly, as workers gain experience in the labour market employers are able to learn about their true productivity and hence need to rely less on a worker's educational level to infer this. Using data for the US the aforementioned studies find support for their employer learning hypothesis, and, similarly, Bauer and HaiskenD eNew (2001) find evidence of this for blue collar workers in Germany.

In order to test whether education may have played a role in dealing with informational uncertainty in $\mathrm{G}$ hana, we in this paper similarly follow the approach taken by Altonji and Pierret (2001) derived from their model of employer learning. In particular, the authors consider the following wage equation:

$\log \left(\mathrm{W}_{\mathrm{i}}\right)=\mathrm{F}\left(\mathrm{T}_{\mathrm{i}}\right)+\beta_{\mathrm{S}} \mathrm{S}_{\mathrm{i}}+\beta_{\mathrm{S}, \mathrm{T}}\left(\mathrm{S}_{\mathrm{i}}^{*} \mathrm{~T}_{\mathrm{i}}\right)+\beta_{\mathrm{Z}} \mathrm{Z}_{\mathrm{i}}+\beta_{\mathrm{Z}, \mathrm{T}}\left(\mathrm{Z}_{\mathrm{i}}^{*} \mathrm{~T}_{\mathrm{i}}\right)+\mu_{\mathrm{I}}$

where $\mathrm{W}$ is the hourly wage rate of worker $\mathrm{i}$ with $\mathrm{T}$ years of work experience, $\mathrm{F}(\mathrm{T})$ are first and higher order terms of $\mathrm{T}, \mathrm{S}$ are the years of schooling, and $\mathrm{Z}$ is a measure of natural ability (only observable to the econometrician) of the individual. Altonji and Pierret (2001)

\footnotetext{
8 The notion that one prediction of the signaling model is that the partial effect of education on earnings declines with labour market experience due to employer learning was proposed as early as by Layard and Psacharopolous (1974) and Psacharopolous (1979).
} 
show that when allowing for $\mathrm{S}$ and $\mathrm{Z}$ to be correlated ${ }^{9}$, then if employers use education as a signal for but also learn about employees' productivity over time, $\beta_{\mathrm{S}, \mathrm{T}}$ should be nonincreasing and $\beta_{\mathrm{Z}, \mathrm{T}}$ non-decreasing. The rationale underlying this is that, because $\mathrm{Z}$ and $\mathrm{S}$ are correlated, employers can derive more information about a worker's true ability the more labour market experience ( $\mathrm{T}$ ) the worker has so that education becomes less important as a signal. If employers, in contrast, have full information about the true productivity of new workers then $\beta_{\mathrm{S}, \mathrm{T}}=\beta_{\mathrm{Z}, \mathrm{T}}=0$.

\section{Section III: Data and Summary Statistics}

O ur data source is the fifth wave, providing information for 1998, of the Regional Programme for Enterprise D evelopment [RPE D ] data for G hana. ${ }^{10,11}$ The RPED is as firm level panel data set of G hanaian manufacturing firms that also surveys up to ten workers in each firm. ${ }^{12}$ At the worker level the information most relevant to the current analysis are the hourly wage rate, education ${ }^{13}$, actual working experience, incidence of on-the-job-training [OJT], and parental schooling, in addition to other standard controls. We also supplement the worker level data with information at the firm level, in particular sector of location,

\footnotetext{
${ }^{9}$ This assumption is the crucial difference to the model in Faber and $\mathrm{G}$ ibbons (1994).

${ }^{10}$ For a more detailed description of this data set see Teal (2000).

11 Our choice of the fifth wave rather than earlier waves was due to its superior information on how the worker heard about his/ her job.

12 The initial sample of 200 firms in 1991 was drawn from the 1987 G hana Census of Manufacturing Activities, stratified by size, sector and location. It should be noted that in the sampling, large firms were oversampled. The sectors from which the firms were chosen are Food, Textiles and Garments, Wood, and Metal, which together comprise about 70 per cent of total manufacturing employment in Ghana. When firms closed down over the period they were replaced with firms in the same size, sector and location categories. Workers were sample according to ten main occupation categories, but unfortunately workers cannot be linked over time.

${ }^{13}$ Education is given as actual levels completed and these were consequently converted to years of schooling. Thanks are due to Francis Teal for help on this.
} 
region, firm size, unionisation, incidence of foreign and state ownership. ${ }^{14}$ Overall this leaves us with a sample of 1,428 workers employed in 188 firms.

In addition to the more standard worker level information that we use, one can also classify workers according to how they heard about their job, and thus into those that were hired through informal channels. Indeed hiring through informal channels seems to be an important aspect of the Ghanian labour market. In an earlier wave of the firm level data in 1991, firms were explicitly asked what their main manner of finding workers was and answers indicated that nearly 30 per cent of firms' dominant way of finding employees was by hiring friends or relatives of the owner or employees already working for the firm. ${ }^{15}$ Arguably, those hired through more informal channels are workers for which employers have superior information about their abilities. For example, using data on the education requirements of vacancies in the Netherlands Albrecht and van Ours (2001) find that employers are more likely to lower their educational standards when more informal recruitment channels are used. Similarly, Albrecht (1981) finds support for this contention using Swedish data for successful and unsuccessful job applicants.

We assume that if a employee heard about the job because he is a friend or relative of the employer, through a friend who is a friend or relative of the employer, or through an employee who is working the firm and who is a friend or relative, that the worker was hired through informal, and otherwise through formal channels. In Table 1 we summarise the responses to the question of the source of the job for our sample of workers. As can be seen, from our total sample 53.5 per cent were hired through informal channels. Of these

\footnotetext{
14 D etailed definitions of the variables used in our analysis are given in the D ata Appendix.

${ }^{15} \mathrm{Not}$ all of these firms are present in the wave that we use for our empirical analysis as some drop out of the sample. Moreover, a number of firms have since then been added to compensate for sample dropouts.
} 
over half had some direct or indirect contact to the employer rather than to an existing employee. ${ }^{16}$

Some summary statistics for our formal and informal channel worker samples are given in Table 2. Accordingly, workers hired through formal channels tend on average to have slightly higher earnings and more work experience than their informal counterparts. Most importantly, we find that workers hired through formal channels have somewhat more education and higher (unobserved) ability, as proxied by parental maximum schooling, than those that find jobs through contacts in the firm. This may be indicative of the possibility that persons with higher abilities may choose greater levels of education at least in part as a signal for jobs acquired through formal channels. The average higher earnings possibly indicate that such jobs are more desirable and/ or require higher productivity.

\section{Section IV - Empirical Results}

In estimating (1) a number of advantages of our data set are noteworthy. Firstly, with regard to T we have, in contrast to Faber and Gibbons (1994), Altonji and Pierret (2001), and, Bauer and Haisken-DeNew (2001), information on the actual, rather than potential, working experience of individuals, thus giving us a much more accurate measure of the time frame available to employers to learn about employees. Secondly, as argued above, our distinction between hiring types allows us to distinguish between two groups for which the importance of educational signaling is likely to differ. However, as a proxy for natural (unobserved to the employer) ability, Z, we, as Bauer and Haisken-D eNew (2001), use the larger of a worker's father's and mother's education measured in years. Ideally, of

16 One should note that evidence from our sample of workers in 1998 suggest that many firms use a combination of formal and informal channels to hire workers. Of the 188 firms 10 had worker samples hired through only formal channels, 27 samples hired through only informal channels and in the samples in the remaining firms both channels were used. 
course, one would like to have access to information such as results of some sort of IQ test, like in Altonji and Pierret (2001), as a more accurate proxy, but unsurprisingly such information is not collected for the RPED data. Having said this, one must point out that Altonji and Pierret (2001) are able to confirm the signaling hypothesis also using father's years of schooling as a proxy for ability. Moreover, in the literature on the returns to education for earnings parental education has widely been used as a measure of unobserved ability. ${ }^{17}$

Our results for estimating (1) for our formal and informal channel workers controlling a large variety of worker and firm level aspects are given in columns one and two of Table 3, respectively. As can be seen, the returns to education are similar between the two groups and are roughly in line with those found for many developed countries. Similarly, the returns to experience appear to be roughly similar, although they are not significant for the formal channel group. ${ }^{18}$ More importantly, looking at our interaction terms we find that for both of these groups we cannot reject the hypothesis that $\beta_{\mathrm{S}, \mathrm{T}}=\beta_{\mathrm{Z}, \mathrm{T}}$ $=0$, implying that employers have full information about their workers' abilities and thus do not 'learn' about their workers' productivities over time. This would suggest that education does not act as a signaling device in G hana manufacturing.

Altonji and Pierret (2001) note that their propositions about the signs of $\beta_{\mathrm{S}, \mathrm{T}}$ and $\beta_{\mathrm{Z}, \mathrm{T}}$ rest on the assumption that the effects of OJT are fully captured by T and other measures of OJT included in (1). As in Altonji and Pierret (2001) and Bauer and Haisken-D eN ew (2001), we have included simple zero-one type dummies ${ }^{19}$ to indicate the incidence of OJT.

\footnotetext{
17 See Card (1999).

${ }^{18}$ In all specification we included the squared value of work experience. We also experimented with higher order terms of this variable, but in no case were these significant.

${ }^{19}$ We used three dummies indicating whether workers were currently receiving OJT, received OJT in the past and whether they received any short training courses in the past.
} 
However, as noted by Bauer and Haisken-D eNew (2001), dummies may not adequately capture differences in OJT across workers. As a matter of fact, for the few workers from our sample for whom there was information on the number of months of OJT received there appears to be a large dispersion in the lengths of $0 \mathrm{JT} .{ }^{20}$ Moreover, it may be that workers who receive OJT are on long-term contracts that explicitly deal with uncertainty. For example, in the widely referred to model by Hashimoto (1981) workers and firms share the cost of OJT, thus generating a steeper wage profile than those that do not receive OJT.

We thus re-estimated (1) separately for those with no and those with at least some OJT for our two different hiring groups ${ }^{21}$, the results of which are given in the last four columns of Table 3. Accordingly, for those with OJT and those without OJT who were hired through informal channels we find similar results to our aggregate samples of hiring groups, i.e., we cannot reject the hypothesis that $\beta_{\mathrm{S}, \mathrm{T}}=\beta_{\mathrm{Z}, \mathrm{T}}=0$. In other words, employers appear to have full information about workers' abilities and thus education does not act as a signaling device. A similar result is found for those hired through formal channels but also receive OJT. In contrast, for those with no OJT who were hired through formal channels $\beta_{\mathrm{S}, \mathrm{T}}$ is now significantly negative and $\beta_{\mathrm{Z}, \mathrm{T}}$ significantly positive, supportive of the use of education as a signaling device for workers' uncertain productivity and employer learning.

\section{Section IV - Conclusion}

Using a simple test of employer learning we investigated whether education is used as signaling device for workers' productivities in G hana manufacturing. O ur results show that where employers hired individuals for whom they are likely to have greater information

\footnotetext{
${ }^{20}$ For many workers information on the actual length of OJT was missing, so that we could not use a continuous indicator in our estimation. The mean and standard deviation of the non-missing data were 46 and 42 months, respectively, thus indicating large differences across workers.

${ }^{21}$ As can be seen those hired through formal channels have a slightly higher incidence of OJT.
} 
by having known them personally or existing employees having known them this is not the case. In contrast, there is supportive evidence for employees hired through more formal channels. This latter result seems to rest on being able to control adequately for the extent of on the job training a worker has accumulated over his/ her lifetime and/ or the possibility that workers who receive on the job training may be on different contractual arrangements that already deal with uncertainty.

On a final note it is important to point out that the fact that education is used as a signaling device does not necessarily mean that standard estimated returns are poor proxies for the true social returns. As shown by Lang(1994), this only likely to be the case where little that is productive is taught in school. Nevertheless, clearly the improvement in and development of labour market channels for the exchange of labour market information can only improve the matching of employees to employers in developing countries. 


\section{References}

Albrecht, J.W. (1981). “ A Procedure for Testing the Signaling Hypothesis”, Journal of Public E conomics, 15, pp. 123-132.

Albrech, J.W. and van O urs, J.C. (2001). "Using E mployer Behavior to Test the Educational Signaling Hypothesis", mimeo.

Altonji, J.G . and Pierret, C.R. (2001). "Employer Learning and Statistical Discrimination", Q uarterly Journal of E conomics, 116, pp. 313-350.

Bauer, T.K. and Haisken-DeNew (2001). "Employer Learning and the Returns to Schooling”, L abour E onomics, 8, pp. 161-180.

Bedard, K. (2001). "Human Capital versus Signaling Models: University Access and High School D ropouts", Journal of Political E conomy, 109, pp. 749-775.

Behrman, J.R. (1999). "Labor Markets in D eveloping Countries", in Handbook of Labor Economics, Vol. 3C, A shenfelter, O . and Card, D . (eds.), Elsevier Science: Amsterdam.

Byrne, D. and Strobl, E. (2001). "D efining Unemployment in Developing Countries: The Case of Trinidad and Tobago", CRED IT (Nottingham) Research Paper, Nr. 01/ 09.

Card, D . (1999). "The Causal Effect of Education on Earnings", in Handbook of Labor Economics, Vol. 3B, Ashenfelter, O and Card, D. (eds.), Elsevier Science: Amsterdam.

Farber, H.S. and Gibbons, R. (1996). "Learning and Wage Dynamics", Q uarterly Journal of E conomics, 111, pp. 1007-1047.

Foster, A.D . and Rosenzweig, M.R. (1994). "Information, Learning and Wages Rate in Rural Labor Markets”, Journal of H uman Resources, 28, pp. 759-790.

Frazis, H. (2002). "Human Capital, Signaling, and the Pattern of Returns to Education", 0 x ford E conomic Papers, 54, pp. 298-320.

Hashimoto, M. (1981). "Firm Specific Human Capital as a Shared Investment", A merican E conomic R eview, 71, pp.475-82.

Lank, K. (1994). "D oes the Human-Capital / Educational-Sorting Debate Matter for Development Policy?", A merican E conomic Review, 84, pp. 353-358.

Layard, R. and Psacharopoulos, G . (1974). "The Screening Hypothesis and the Returns to Education", Journal of Political E onomy, 82, pp. 985-998.

Psacharopoulos, G. (1979). "On the Weak versus the Strong Version of the Screening Hypothesis", E conomics L etters, 4, pp. 181-185. 
Teal, F. (2000) "Real wages and the demand for skilled and unskilled male labour in G hana's manufacturing sector: 1991-1995", Journal of D evelopment E conomics, 61, pp. 447-461.

Weiss, A. (1995). "Human Capital vs. Signaling Explanations of Wages", Journal of E conomic Perspectives, 9, pp. 133-154. 


\section{Table 1: How did You Hear about Your Present Employer}

\begin{tabular}{|l|c|}
\hline SOURCE & $\%$ \\
\hline Employer (Friend) & 7.3 \\
\hline E mployer (Relative) & 12.1 \\
\hline Employer (Friend or Relative of Friend) & 10.3 \\
\hline Employee (Friend) & 8.2 \\
\hline Employee (Relative) & 15.6 \\
\hline Somebody with No Connection to the Firm & 15.6 \\
\hline Church or Mosque & 1.1 \\
\hline Advertisement & 20.8 \\
\hline Other & 9.0 \\
\hline
\end{tabular}

\section{Table 2: Summary Statistics (Means) by Hiring Channel}

\begin{tabular}{|l|c|c|}
\hline & Formal & Informal \\
\hline Log(H ourly Wage Rate) [W] & 1.4 & 1.1 \\
\hline Actual Work Experience (years) [T] & 13.5 & 11.9 \\
\hline Schooling (years) [S] & 11.3 & 10.0 \\
\hline Maximum of Parent's Schooling (years) [Z] & 6.9 & 6.4 \\
\hline On-the-Job-Training [OJT] & $45 \%$ & $42 \%$ \\
\hline
\end{tabular}

Table 3: Wage Equation

\begin{tabular}{|c|c|c|c|c|c|c|}
\hline & (1) & (2) & (3) & (4) & (5) & (6) \\
\hline \multirow[t]{2}{*}{$T$} & 0.013 & $0.017^{* *}$ & 0.019 & 0.012 & 0.015 & $0.038 * * *$ \\
\hline & (0.009) & $(0.007)$ & $(0.015)$ & $(0.012)$ & $(0.010)$ & $(0.011)$ \\
\hline \multirow[t]{2}{*}{$\mathbf{S}$} & $0.032 * * *$ & $0.033^{* * *}$ & $0.036 * *$ & $0.031 * * *$ & $0.046 * * *$ & $0.040 * * *$ \\
\hline & $(0.009)$ & $(0.010)$ & $(0.016)$ & $(0.011)$ & $(0.015)$ & $(0.014)$ \\
\hline \multirow[t]{2}{*}{$\mathbf{Z}$} & -0.007 & -0.003 & -0.015 & -0.004 & -0.005 & -0.006 \\
\hline & $(0.006)$ & (0.006) & $(0.009)$ & (0.009) & (0.011) & (0.008) \\
\hline \multirow[t]{2}{*}{$\left(\mathrm{S}^{*} \mathrm{~T}\right) / 100$} & 0.003 & -0.050 & 0.026 & -0.056 & -0.046 & $-0.146^{*}$ \\
\hline & $(0.053)$ & $(0.057)$ & (0.106) & $(0.067)$ & $(0.085)$ & $(0.079)$ \\
\hline \multirow[t]{2}{*}{$(\mathrm{Z} * \mathrm{~T}) / 100$} & 0.011 & 0.047 & -0.018 & 0.041 & 0.049 & $0.085^{*}$ \\
\hline & (0.041) & (0.037) & $(0.068)$ & (0.056) & (0.063) & (0.048) \\
\hline Constant & $\begin{array}{c}-1.100^{* * *} \\
(0.367)\end{array}$ & $\begin{array}{l}-0.062 \\
(0.560)\end{array}$ & $\begin{array}{c}-1.009 * * \\
(0.423)\end{array}$ & $\begin{array}{c}-0.856^{* *} \\
(0.336)\end{array}$ & $\begin{array}{l}-0.620 \\
(0.620)\end{array}$ & $\begin{array}{l}-0.607 \\
(0.385)\end{array}$ \\
\hline Sample & $\mathrm{DC}$ & N-DC & $\mathrm{DC}, \mathrm{OJT}$ & DC, N-OJT & N-D C, OJT & N-DC, N-OJT \\
\hline Obs. & 799 & 629 & 323 & 470 & 258 & 371 \\
\hline F-Test & $20.53^{* * *}$ & $28.72^{* * *}$ & $11.31 * * *$ & $12.67 * * *$ & $17.75^{* * *}$ & $15.71 * * *$ \\
\hline R-squared & 0.51 & 0.66 & 0.59 & 0.51 & 0.76 & 0.63 \\
\hline
\end{tabular}

Notes: (1) ${ }^{* * *}, * *$, and $* *$ are 1,5 , and 10 per cent significance levels, respectively. (2) Standard errors in parentheses. (3) DC: direct contacts; N-D C: no direct contacts; OJT: on-thejob-training; N-OJT: no on-the job-training. (4) Other worker level controls in model are the squared value of $\mathrm{T}$, gender, race, union status, occupation, dummies, and dummies for present OJT, past OJT, and short training course. (5) Firm level controls included regional and industry dummies, firm size, percentage unionized, percentage foreign ownership, and state ownership dummy. (5) Actual working experience squared included. 


\section{DATA APPENDIX}

\begin{tabular}{|l|l|}
\hline Hourly Wage Rate [W] & logged value of hourly wage rate \\
\hline Work Experience [T] & actual work experience in years; \\
\hline Education [S] & years of schooling \\
\hline Ability [Z] & maximum years of parent's schooling \\
\hline On-the Job-Training [0JT] & three dummies for whether (1) current OJT (2) past OJT and (3) past OJT \\
\hline Gender & dummy for male \\
\hline Union & dummy for union membership \\
\hline Race & dummy for Caucasian \\
\hline Occupation & 19 occupation dummies \\
\hline Industry & 4 sector dummies \\
\hline Location & 4 regional dummies \\
\hline Firm Size & total employment in firm \\
\hline State Ownership & dummy for any state ownership \\
\hline Foreign Ownership & percentage of foreign ownership \\
\hline
\end{tabular}




\section{IZA Discussion Papers}

\begin{tabular}{|c|c|c|c|c|}
\hline No. & Author(s) & Title & Area & Date \\
\hline 667 & $\begin{array}{l}\text { P. Arnds } \\
\text { H. Bonin }\end{array}$ & $\begin{array}{l}\text { Arbeitsmarkteffekte und finanzpolitische Folgen } \\
\text { der demographischen Alterung in Deutschland }\end{array}$ & 7 & $12 / 02$ \\
\hline 668 & $\begin{array}{l}\text { J. Meckl } \\
\text { S. Zink }\end{array}$ & $\begin{array}{l}\text { Solow and Heterogeneous Labor: A } \\
\text { Neoclassical Explanation of Wage Inequality }\end{array}$ & 3 & $12 / 02$ \\
\hline 669 & $\begin{array}{l}\text { A. C. D'Addio } \\
\text { I. De Greef } \\
\text { M. Rosholm }\end{array}$ & $\begin{array}{l}\text { Assessing Unemployment Traps in Belgium } \\
\text { Using Panel Data Sample Selection Models }\end{array}$ & 2 & $12 / 02$ \\
\hline 670 & $\begin{array}{l}\text { M. Botticini } \\
\text { Z. Eckstein }\end{array}$ & $\begin{array}{l}\text { From Farmers to Merchants: A Human Capital } \\
\text { Interpretation of Jewish Economic History }\end{array}$ & 5 & $12 / 02$ \\
\hline 671 & $\begin{array}{l}\text { A. Constant } \\
\text { S. Konstantopoulos }\end{array}$ & $\begin{array}{l}\text { School Effects and Labor Market Outcomes for } \\
\text { Young Adults in the 1980s and 1990s }\end{array}$ & 1 & $12 / 02$ \\
\hline 672 & $\begin{array}{l}\text { A. Constant } \\
\text { D. Massey }\end{array}$ & $\begin{array}{l}\text { Self-Selection, Earnings, and Out-Migration: A } \\
\text { Longitudinal Study of Immigrants to Germany }\end{array}$ & 1 & $12 / 02$ \\
\hline 673 & $\begin{array}{l}\text { A. L. Booth } \\
\text { M. Francesconi } \\
\text { J. Frank }\end{array}$ & $\begin{array}{l}\text { Labour as a Buffer: Do Temporary Workers } \\
\text { Suffer? }\end{array}$ & 2 & $12 / 02$ \\
\hline 674 & $\begin{array}{l}\text { D. A. Cobb-Clark } \\
\text { V. Hildebrand }\end{array}$ & $\begin{array}{l}\text { The Wealth and Asset Holdings of U.S.-Born } \\
\text { and Foreign-Born Households: Evidence from } \\
\text { SIPP Data }\end{array}$ & 6 & $12 / 02$ \\
\hline 675 & $\begin{array}{l}\text { J. Konings } \\
\text { O. Kupets } \\
\text { H. Lehmann }\end{array}$ & $\begin{array}{l}\text { Gross Job Flows in Ukraine: Size, Ownership } \\
\text { and Trade Effects }\end{array}$ & 4 & $12 / 02$ \\
\hline 676 & A. Voicu & $\begin{array}{l}\text { Agriculture: Transition Buffer or Black Hole? A } \\
\text { Three-State Model of Employment Dynamics }\end{array}$ & 4 & $12 / 02$ \\
\hline 677 & $\begin{array}{l}\text { F. Galindo-Rueda } \\
\text { A. Vignoles }\end{array}$ & $\begin{array}{l}\text { Class Ridden or Meritocratic? An Economic } \\
\text { Analysis of Recent Changes in Britain }\end{array}$ & 2 & $12 / 02$ \\
\hline 678 & $\begin{array}{l}\text { M. Barbie } \\
\text { M. Hagedorn } \\
\text { A. Kaul }\end{array}$ & $\begin{array}{l}\text { Fostering Within-Family Human Capital } \\
\text { Investment: An Intragenerational Insurance } \\
\text { Perspective of Social Security }\end{array}$ & 3 & $12 / 02$ \\
\hline 679 & $\begin{array}{l}\text { A. Kölling } \\
\text { C. Schnabel } \\
\text { J. Wagner }\end{array}$ & $\begin{array}{l}\text { Establishment Age and Wages: Evidence from } \\
\text { German Linked Employer-Employee Data }\end{array}$ & 1 & $12 / 02$ \\
\hline 680 & $\begin{array}{l}\text { M. Hagedorn } \\
\text { A. Kaul }\end{array}$ & $\begin{array}{l}\text { Langzeitarbeitslosigkeit in Deutschland: Fakten, } \\
\text { Ursachen und Bekämpfung }\end{array}$ & 7 & $12 / 02$ \\
\hline 681 & $\begin{array}{l}\text { M. Hagedorn } \\
\text { A. Kaul } \\
\text { T. Mennel }\end{array}$ & $\begin{array}{l}\text { An Adverse Selection Model of Optimal } \\
\text { Unemployment Insurance }\end{array}$ & 7 & $12 / 02$ \\
\hline 682 & B. Cockx & $\begin{array}{l}\text { Vocational Training of Unemployed Workers in } \\
\text { Belgium }\end{array}$ & 2 & $01 / 03$ \\
\hline 683 & E. Strobl & $\begin{array}{l}\text { Is Education Used as a Signaling Device for } \\
\text { Productivity in Developing Countries? Evidence } \\
\text { from Ghana }\end{array}$ & 4 & $01 / 03$ \\
\hline
\end{tabular}

